\title{
INTEGRASI PARTICIPATORY PLANT BREEDING DAN PREFERENSI KONSUMEN: PELUANG PENERAPANNYA DALAM PENGEMBANGAN VARIETAS KEDELAI BARU DI INDONESIA
}

\author{
Dika Supyandi ${ }^{1}$, Yayat Sukayat ${ }^{1}$, Meddy Rachmadi ${ }^{2}$ \\ ${ }^{1}$ Departemen Sosial Ekonomi Pertanian Universitas Padjadjaran; \\ ${ }^{2}$ Departemen Budidaya Pertanian Universitas Padjadjaran; \\ Jl. Raya Bandung Sumedang Km. 21 Jatinangor, Sumedang, Jawa Barat \\ Email: dika.supyandi@unpad.ac.id
}

\begin{abstract}
ABSTRAK
Metode pemuliaan tanaman formal tidak selalu sesuai dengan kebutuhan, terkait dengan beragamnya kondisi agroekosistem pertanaman dan sosial budaya masyarakat serta karakteristik produk benih yang dibutuhkan. Karakteristik benih yang dibutuhkan dapat ditelusur dari pengguna itu sendiri, yang bukan hanya di tingkat petani pengguna benih, tetapi juga sampai pada konsumen akhir pengguna produk usahatani. Salah satu pendekatan yang saat ini mulai banyak digunakan dalam kegiatan pemuliaan tanaman adalah participatory plant breeding (PPB). Dalam pendekatan ini, petani beserta pelaku lainnya, seperti penyuluh pertanian dan peneliti pemulia, berpartisipasi dalam pengembangan varietas baru. Kata participatory berarti bahwa aktivitas pemuliaan tanaman ini bersifat inklusif, mempromosikan keragaman genetik, serta memberdayakan petani dan masyarakat perdesaan. PPB dapat dikenali dari tujuannya (pendekatan proses atau fungsional), konteks kelembagaannya (farmer led atau formal led), dan bentuk interaksi antar petani dan pemulia (konsultatif, kolaboratif, atau kolegial). Namun demikian, upaya pemuliaan kedelai saat ini, seyogyanya diantisipasi tidak hanya sampai pada tingkat petani pengguna tetapi lebih jauh lagi hingga tingkat pengguna akhir, dalam hal ini para pengrajin pangan berbahan baku kedelai. Oleh karenanya, integrasi antara pendekatan pemuliaan kedelai yang lebih partisipatif dengan produksi yang didorong permintaan pasar harus menjadi perhatian. Artikel ini adalah studi literatur, mendeskripsikan cara mengimplementasikan PPB, perhatian terhadap preferensi konsumen akhir kedelai dan peluang penerapan integrasi antara PPB dan preferensi konsumen dalam pengembangan varietas kedelai baru di Indonesia. Sejumlah prasyarat harus dipenuhi dalam penerapan PPB, khususnya dalam konteks pengembangan varietas kedelai baru.
\end{abstract}

Kata kunci: pengembangan varietas kedelai, participatory plant breeding

\begin{abstract}
Formal led plant breeding has not been always suitable with the needs, related to variance of environmental and socio-cultural conditions and needed seed characteristics. Needed seed characteristics could be traced from the users, which is not only at seed user farmers level, but also at end consumers. Participatory plant breeding has begun to be a popular approach in plant breeding activities, where farmers with other actors, such as agriculture extension officers and plant breeding researchers work together to develop new variety of plants. The word "participatory" means that this activity is inclusive, promote genetics variability, and empower farmers as well as rural community. Participatory plant breeding can be recognized from the goals (process approach or functional approach), institutional contexts (farmer led or formal led), and interaction between farmers and breeders (consultative, collaborative, or collegial). However, recent soybean breeding efforts should be anticipated not only at user farmer level, but also at end user, namely food industries using soybean as raw material. This paper is a literature study; describe means to implement participatory plant breeding, attentions toward soybean's end consumer preferences, and the implementation opportunity of integration between PPB and consumer preference to develop new soybean variety in Indonesia. Several preconditions are needed to implement participatory plant breeding, particularly in the context of development of new soybean variety.
\end{abstract}

Keywords: soybean variety improvement, participatory plant breeding 


\section{PENDAHULUAN}

Efisiensi pemanfaatan sumberdaya dalam upaya menghasilkan produk pertanian yang memiliki keunggulan kompetitif dalam era otonomi daerah dan globalisasi menjadi tuntutan yang tidak dapat dihindari. Dari sisi otonomi daerah, pelimpahan kewenangan bidang pertanian ke tingkat pemerintah daerah menuntut perbaikan struktur birokrasi daerah. Era globalisasi ekonomi, termasuk diantaranya Masyarakat Ekonomi Asean mengaburkan batas-batas wilayah yang melahirkan persaingan ketat. Selain itu, keterlibatan masyarakat sebagai upaya pemberdayaan masyarakat juga menjadi tuntutan yang mendominasi aktivitas pembangunan saat ini.

Lebih jauh lagi, dalam era market driven economy saat ini, pemenuhan ekspektasi dan preferensi konsumen merupakan pendorong dan penggerak aktivitas produksi, tidak terkecuali produk pertanian. Ini berarti keuggulan sebuah produk dapat diartikan sebagai sejauh mana produk tersebut dia dapat memenuhi kebutuhan dan ekspektasi konsumen. Dalam konteks pemuliaan tanaman, produk yang sesuai dengan kebutuhan konsumen akan sangat ditentukan oleh sejauh mana varietas unggul yang dihasilkan dapat diadopsi dan dibudidayakan di tingkat usahatani sesuai dengan kondisi agroekosistem dan sosial budayanya.- Varietas unggul yang seperti itu merupakan faktor pertama pendukung keberhasilan usahatani. Oleh karena itu, mengidentifikasi harapan dan kebutuhan konsumen pada dasarnya merupakan langkah penting yang tidak dapat ditinggalkan.

Metode pemuliaan tanaman formal (formal plant breeding/FPB) dipandang tidak mampu menghasilkan varietas unggul yang sesuai dengan ekspektasi dan preferensi konsumen; karena beragamnya kondisi agroekosistem pertanaman dan sosial budaya masyarakat serta karakteristik produk benih yang dibutuhkan. Karakteristik benih yang dibutuhkan dapat ditelusur dari pengguna itu sendiri, yang bukan hanya di tingkat petani pengguna benih, tetapi juga sampai pada konsumen akhir pengguna hasil usahatani.

Alternatif pendekatan yang saat ini mulai banyak digunakan dalam kegiatan pemuliaan tanaman adalah participatory plant breeding (PPB). Dalam pendekatan ini, petani beserta pelaku lainnya seperti penyuluh pertanian, dan peneliti pemulia berpartisipasi dalam pengembangan varietas baru. Kata participatory berarti bahwa kegiatan pemuliaan tanaman ini bersifat inklusif, mempromosikan keragaman genetik dan responnya terhadap keragaman agroekosistem pertanaman dan sosial budaya masyarakat, serta sekaligus memberdayakan petani dan masyarakat perdesaan.

Pengembangan varietas unggul sebagai inti dari kegiatan pemuliaan tanaman pada dasarnya adalah kegiatan inovasi produk. Kegiatan tersebut bermula dari perekayasaan teknologi dan diakhiri oleh adopsi teknologi. Perekayasaan teknologi perakitan varietas unggul baru meliputi pemilihan tetua, rekombinasi gen, seleksi galur, pengujian daya penampilan, pengujian multilokasi, dan pelepasan varietas unggul baru. Dalam pemuliaan tanaman formal, rangkaian kegiatan tersebut pada umumnya dilakukan oleh para pemulia tanaman penanggung jawab kegiatan pemuliaan tanaman di kebun percobaan; kecuali untuk kegiatan pengujian multilokasi. Kondisi tersebut bukannya tidak memberikan konsekuensi. Menurut Ceccarelli (2007), prosedur seperti itu yang tidak atau terbatas melibatkan partisipasi petani dengan kondisi lokasinya yang spesifik dapat menyebabkan berbedanya karakteristik keunggulan yang diminati pengguna/petani dan juga dapat menyebabkan tingkat adopsi teknologi varietas unggul pada suatu lokasi/lingkungan sangat rendah.

Pada dasarnya, keunggulan suatu varietas tanaman ditentukan oleh kemampuannya untuk memanfaatkan faktor-faktor lingkungan di sekitarnya. Menurut Falconer dan Mackay (1996) suatu varietas tanaman dikatakan unggul apabila varietas tersebut mampu mengatasi permasalahan interaksi genotipe $\mathrm{x}$ lingkungan. Hal tersebut karena sesungguhnya, setiap varietas tanaman memiliki spesifikasi tertentu terhadap lingkungan pertumbuhannya; dikenal sebagai pendekatan spesifik lingkungan. Dengan demikian, lingkungan atau lokasi yang berbeda pada dasarnya membutuhkan varietas unggul yang berbeda. Lebih lanjut, petani kecil seringkali harus menanam pada lahan dengan kondisi yang tidak menguntungkan (unfavorable condition); misal pada lingkungan yang rawan kekeringan. Dalam kondisi tersebut, pemuliaan tanaman formal-seringkali gagal merakit varietas yang toleran pada kondisi lingkungan yang serupa itu. Hasil kegiatan pemuliaan tanaman formal lebih ditujukan untuk kondisi lahan dengan kondisi yang menguntungkan (favorable 
condition); karena pada umumnya kegiatannya dilaksanakan pada kondisi seperti itu.

Saat ini, penerapan PPB mulai banyak dilakukan dalam upaya pemuliaan berbagai komoditas tanaman. Hanya saja ditengarai bahwa pelaksanaan PPB masih berkisar pada partisipasi pelaku pada tingkat budidaya (kebutuhan petani pengguna benih). Dengan demikian, kesesuaian kebutuhan konsumen masih berada pada konsumen antara, dalam hal ini petani pengguna benih, bukan pada tingkat konsumen akhir; terutama para pengrajin pangan pengguna kedelai sebagai bahan baku produknya.

Di Indonesia, kedelai merupakan salah satu sumber pangan pokok dan strategis, sebagai sumber protein nabati yang menyehatkan, dan secara ekonomi terjangkau oleh masyarakat. Kedelai dimanfaatkan menjadi banyak produk turunan di Indonesia, untuk konsumsi manusia, pakan ternak dan benih (CGPRT, 1987). Lebih lanjut CGPRT menyatakan bahwa kedelai untuk konsumsi manusia tersedia dalam berbagai bentuk olahan seperti tempe, tahu, tauco, dan kecap; dan beberapa bentuk lain, seperti tauge, sere di Bali, yuba, dan susu kedelai. Hanya sedikit kedelai dipakai untuk pakan ternak, khususnya ayam, meskipun jumlahnya semakin meningkat.

Selain sumber protein, kedelai juga telah menjadi sumber lemak dan penyedap yang penting bagi masyarakat Indonesia. Berbagai macam pangan dari kedelai dapat digolongkan dalam dua kelompok: yang diragikan dan yang tidak diragikan. Produk utama kedelai ragian di Indonesia adalah tempe, oncom, tauco, dan kecap. Produk-produk yang bukan ragian meliputi tahu, tauge, susu kedelai, kedelai goreng (sebagai kudapan), kedelai rebus (juga sebagai kudapan), dan kedelai yang dimasak sebagai sayur atau bahan sop.

Balai Penelitian Kacang-kacangan dan Umbi-umbian (2008) menyatakan bahwa dewasa ini kedelai tidak hanya digunakan sebagai sumber protein, tetapi juga sebagai pangan fungsional untuk mencegah timbulnya penyakit degeneratif, seperti jantung koroner dan hipertensi. Zat isoflavon yang ada pada kedelai ternyata berfungsi sebagai antioksidan.

Seiring dengan pertumbuhan populasi Indonesia, dan beragamnya pemanfaatan kedelai, permintaan terhadap kedelai juga terus meningkat. Darmardjati et al. (2015) dalam Facino (2012) menyebutkan bahwa total konsumsi kedelai di Indonesia terus tumbuh dari 2.179 ton (2006) menjadi 2.407 ton (2010) dan diproyeksikan di angka 2.708 ton (2015). Selanjutnya Facino mengungkapkan bahwa pemenuhan permintaan ini dipenuhi sebagian besar oleh impor, padahal di masa jayanya antara tahun 1991-1996, Indonesia memproduksi lebih dari 1,5 juta ton per tahun. Angka ini menutup sekitar 80 persen dari kebutuhan lokal. Namun, produksi kedelai nasional dalam dekade terakhir tidak dapat melampaui 1 juta ton per tahunnya.

Di sisi lain, selain aspek ketersediaan produksi, pilihan konsumen akhir terhadap varietas kedelai harus menjadi salah satu perhatian utama. Meskipun saat ini telah diperoleh sejumlah varietas unggul baru yang memiliki produktivitas tinggi, serta mutu fisik dan gizi kedelai nasional dinyatakan lebih baik dari kedelai impor (Balai Penelitian Kacangkacangan dan Umbi-umbian, 2008), diduga para pengrajin olahan kedelai lebih menyukai kedelai impor. Hal tersebut karena ukuran biji kedelai nasional dianggap kecil dan kurang mengembang pada saat diolah.

Oleh karenanya, upaya pemuliaan kedelai baru tidak dapat hanya fokus pada peningkatan produksi dari sisi kuantitas dan perhatian terhadap kondisi cekaman lingkungan saja, tetapi juga harus mempertimbangkan kebutuhan konsumen akhir, dalam hal ini para pengrajin berbahan baku kedelai.

\section{METODE PENELITIAN}

Artikel ini adalah studi literatur, mendeskripsikan cara mengimplementasikan PPB, sejumlah praktik terbaik pelaksanaan PPB dan peluang penerapannya dalam pengembangan varietas kedelai baru di Indonesia.

\section{HASIL DAN PEMBAHASAN Participatory Plant Breeding (PPB)}

Sebagai penentu keberhasilan dalam penyediaan benih bermutu, pemuliaan tanaman berperan sangat penting dalam memperkuat sistem pertanian lokal dan konservasi keanekaragaman genetis (Elings et al., 2001). Selanjutnya ia menyebutkan bahwa, pemuliaan tanaman yang partisipatif memiliki sejumlah keunggulan, diantaranya definisi yang lebih baik dari kriteria seleksi yang penting bagi komunitas lokal, dan target kondisi lingkungan yang lebih baik.

Pelibatan petani dalam kegiatan pemuliaan tanaman mulai dikenal lebih luas 
sebagai Participatory Plant Breeding (PPB). Kegiatan yang melibatkan petani tersebut pada dasarnya mencakup keseluruhan aspek kegiatan pemuliaan tanaman, mulai dari eksplorasi plasma nutfah, pemilihan tetua sebagai sumber gen, rekombinasi genetik, seleksi galur, pengujian galur, dan pengujian multilokasi/ multilingkungan (Sperling et al., 2001). Menurut Almekinders dan Elings (2001), pendekatan PPB terutama akan dapat menghasilkan varietas unggul yang sesuai dengan preferensi petani/pengguna, memanfaatkan sumber daya lokal secara optimal, menghasilkan varietas unggul spesifik lokasi, meningkatkan adopsi varietas unggul, dan pada akhirnya akan meningkatkan produksi tanaman. Menurut Falconer dan Mackay (1996), suatu varietas unggul spesifik lokasi akan mampu beradaptasi baik pada lokasi tersebut sehingga memberikan hasil yang optimal sesuai dengan kondisi dan daya dukung di lokasi pertanaman tersebut.

Berbeda dengan FPB, kegiatan PPB pada umumnya dilakukan pada lahan yang tidak menguntungkan. Pada kondisi seperti itu dikhawatirkan ekspresi genetik tanaman tidak terskepresikan sehingga program pemuliaan tanaman mengalami kegagalan. Namun Banzinger dan Cooper (2001) melaporkan bahwa pengembangan varietas jagung dan gandum melalui PPB pada kondisi lingkungan yang tidak menguntungkan masih masih dapat dikembangkan. Hal yang sama dilaporkan oleh Machado dan Fernandes (2001) pada PPB jagung dengan kondisi kandungan nitrogen rendah. Menurut Curtois dkk. (2001), kombinasi tugas antara pemulia tanaman dengan petani dalam PPB akan menghasilkan varietas unggul yang lebih sesuai dengan kondisi lingkungannya yang akan memberikan keuntungan bagi petani.

Elings et al. (2001) selanjutnya menyatakan bahwa pengetahuan peneliti dan petani sama pentingnya dalam PPB. Varietas unggul hasil kegiatan pemuliaan tanaman biasanya dihadapkan pada permasalahan kondisi lingkungan yang marginal dan interaksi genotipe $\mathrm{x}$ lingkungan yang besar, sehingga sangat mempengaruhi produktivitas pertanaman. Oleh karena itu, pengetahuan petani tentang karakterisitik agroekosistem lahan dan kesesuaiannya sebagai lingkungan pengujian (site trial) dengan lingkungan target (site target) dimana varietas unggul kelak akan dikembangkan akan menentukan keefektifan dari PPB.
Beberapa pihak meragukan bahwa petani dapat melakukan kegiatannya di dalam PPB. Ceccarelli dkk. (2001) menunjukkan bahwa sesungguhnya petani dapat melakukan hampir semua kegiatan PPB; kecuali penanganan dan pencatatan data. Bahkan menurutnya, petani juga dapat melakukan seleksi secara efektif; baik terhadap populasi yang masih bersegregasi maupun galur-galur yang sudah stabil. Namun demikian menurut Banzinger dan Cooper (2001) dan Ceccarelli dkk. (2000), kegiatan PPB sebaiknya diarahkan pada areal pengembangan tertentu dan tidak pada areal pengembangan dengan kondisi agroekosistem yang sangat beragam.

Pada pendekatan PPB, petani berperan dan bertanggungjawab terhadap sebagian atau sebagian besar proses kegiatan pemuliaan tanaman dalam rangka menghasilkan varietas unggul yang beradaptasi pada lingkungan spesifik. Pada kegiatan seperti itu, petani berperan aktif dalam kegiatan-kegiatan pemuliaan tanaman baik di areal pengujian maupun areal target di lahan petani itu sendiri (Maurya et al., 1988; Joshi et al., 2001).

Kegiatan PPB pada dasarnya merupakan kegiatan bersama antara pemulia tanaman dengan petani dalam menghasilkan varietas unggul. Peran petani terutama dalam memastikan tujuan pemuliaan tercapai untuk memenuhi preferensi dan kebutuhan petani sesuai dengan kondisi lingkungan targetnya. Sedangkan pemulia tanaman berperan dalam pembentukan keragaman genetik, pengelolaan populasi, dan pengembangan rancangan seleksi untuk memisahkan pengaruh genetik dari pengaruh lingkungan (Sobir, 2005)

\section{Pemuliaan Tanaman Kedelai}

Salah satu permasalahan utama budidaya kedelai adalah ketersediaan benih bermutu. Penyediaan benih kedelai bermutu selama ini hampir selalu dilakukan atas tanggung jawab pemerintah. Menurut Sadjad (2001) dalam Rachmadi dkk. (2015), pemenuhan kebutuhan benih harus mencakup aspek-aspek tepat jumlah, tepat varietas, tepat mutu, tepat lokasi, tepat waktu, dan tepat harga. Pada tahun 2014, untuk luasan areal 615.019 ha pertanaman kedelai, pemerintah harus menyediakan benih sekitar 24.600 ton; dengan asumsi kebutuhan benih kedelai adalah $40 \mathrm{~kg} / \mathrm{ha}$. Sejauh ini, penyediaan benih kedelai secara kuantitas untuk satu atau beberapa varietas tampaknya tidak menjadi masalah. Namun kondisi 
agroekosistem pertanaman kedelai serta kondisi sosial budaya bertani petani kedelai yang bervariasi akan menuntut varietas kedelai yang spesifik sesuai dengan kondisi-kondisi tersebut. Hal tersebut dapat menjadi bermasalah dalam penyediaan varietas unggul oleh pemerintah, karena berarti pemerintah harus menyediakan berbagai benih bermutu dari verietas kedelai yang berbeda dengan volume masing-masing relatif lebih kecil.

Kegiatan pemuliaan tanaman kedelai telah berkembang pesat di Indonesia. Pada rentang waktu 95 tahun, sejak tahun 1918 sampai dengan 2012, telah dilepas 78 varietas unggul kedelai yang memiliki potensi hasil tinggi (Kementan, 2013). Dalam kurun waktu 20 tahun terakhir, pemerintah telah melepas tidak kurang dari 40 varietas unggul kedelai; atau rata-rata kecepatan pelepasan varietas sebesar 2 varietas unggul per tahun.

Laju pelepasan varietas unggul kedelai yang tinggi sangat diharapkan terutama bagi negara dengan kondisi agroekosistem yang sangat bervariasi seperti Indonesia. Saat ini, tingkat adopsi varietas unggul baru kedelai tidak sebanding dengan laju pelepasan varietas unggul baru. Selama rentang 20 tahun terakhir, dari tidak kurang 40 varietas unggul yang telah dilepas, hanya lima varietas unggul kedelai yang digunakan petani secara luas; atau sekitar $12,5 \%$ dari keseluruhan varietas unggul. Varietas-varietas unggul tersebut adalah Burangrang (dilepas tahun 1995), Anjasmoro (2001), Baluran (2002), Panderman (2003), dan Grobogan (2008). Varietas-varietas unggul tersebut pada dasarnya memiliki karakteristik unggul sesuai preferensi petani/pengguna, seperti daya hasil tinggi, umur panen relatif genjah, dan ukuran biji besar, namun apabila dilihat lebih mendalam dan spesifik, mungkin hanya varietas Anjasmoro saja yang sampai sekarang masih tetap lebih disukai petani. Kondisi serupa juga terlihat selama 12 tahun sebelumnya (1983 - 1995), dari sejumlah 25 varietas unggul yang dilepas, hanya varietas Wilis yang digunakan oleh petani/pengguna. Kebanyakan varietas unggul kedelai yang telah dilepas tidak diadopsi, tidak berkembang, dan tidak dimanfaatkan petani/pengguna, serta kurang berkontribusi pada upaya peningkatan produksi kedelai (Rachmadi dkk., 2015).

Menurut Kaindaneh (2006), adopsi varietas unggul baru pada dasarnya dipengaruhi sejumlah faktor, antara lain 1) umur petani, 2) akses dari penyuluhan, 3) akses untuk mendapatkan komponen produksi, 4) hasil yang dapat dicapai, 5) karakteristik vegetasi dan pertumbuhan tanaman, 6) populasi tanaman, 7) tanaman pesaing lain, 8) preferensi konsumen, dan 9) persepsi petani terkait dengan manfaat dari varietas unggul baru tersebut. Berdasarkan survey pada tahun 2012 di sentra-sentra produksi kedelai di Indonesia, faktor penghambat adopsi varietas unggul kedelai oleh petani adalah tidak tersedianya benih pada saat yang dibutuhkan, karakteristik varietas unggul/benih bermutu tidak sesuai keinginan petani, harga benih mahal, dan lokasi penjualan benih jauh dari lokasi usahatani (Krisdiana, 2014). Oleh karena itu jelas bahwa adopsi suatu varietas unggul hakekatnya tidak hanya didasarkan pada keunggulan biologis dari varietas tersebut, namun juga ditentukan oleh faktor eksternal petani sebagai pengguna dan faktor lingkungan fisik sebagai pendukung keberhasilan usahatani.

Sementara itu, terkait dengan kualitas produksi kedelai, berdasarkan warna kulitnya, kedelai dapat dibedakan atas kedelai putih, kedelai hitam, kedelai coklat, dan kedelai hijau. Kedelai yang ditanam di Indonesia adalah kedelai kuning atau putih, hitam dan hijau. Perbedaan warna tersebut akan berpengaruh dalam penggunaan kedelai sebagai bahan pangan. Menurut SNI 01-3922-1995, klasifikasi atribut mutu kedelai dibagi ke dalam 4 tingkatan, berdasarkan jenis uji kadar air, butir belah, butir rusak, butir warna lain, butir keriput dan kotoran. Syarat mutu kedelai secara umum adalah :1) bebas hama penyakit. 2) bebas bau busuk, bau asam, bau apek, dan bau asing lainnya, 3) bebas dari bahan kimia seperti insektisida dan fungisida.4) memiliki suhu normal.

Dari sisi petani produsen, sejumlah atribut benih kedelai yang baik adalah memenuhi standar mutu berikut: 1) murni dan diketahui nama varietasnya, 2) memiliki daya tumbuh tinggi (>85\%) dan vigornya baik, 3 ) diperoleh dari tanaman yang telah masak, sehat, dan tidak terkena penyakit virus, 4) biji sehat, bernas, mengkilat, tidak keriput, dan tidak terinfeksi cendawan dan bakteri, 5) biji bersih, tidak tercampur biji tanaman lain, atau biji rerumputan (Balitbangtan Irja, 2000).

Partisipasi petani dalam kegiatan perakitan dan seleksi varietas unggul kedelai dapat diperluas. Labrada (2009) dalam Rachmadi dkk. (2015) menawarkan konsep baru dalam produksi dan difusi benih. Konsep 
tersebut didasari oleh paradigma yang belakangan ini berkembang terutama di negara berkembang, bahwa produksi benih yang terdesentralisasi akan lebih efisien terutama apabila sasaran difusi benih bersifat spesifik. Pada kondisi yang terdesentralisasi dengan kondisi agroekosistem yang sangat bervariasi, keterlibatan petani diarahkan agar mampu melaksanakan kegiatan pemuliaan tanaman sekaligus kegiatan produksi benih. Dengan demikian petani difungsikan sebagai pemulia tanaman sekaligus pelaku perbenihan.

Menurut Rachmadi (2016), kegiatan partisipatif di bidang perbenihan yang terdesentralisasi dapat memberikan manfaat, antara lain: (1) Benih bermutu yang dihasilkan terjamin kemurnian genetisnya sesuai dengan preferensi petani/penggunanya; (2) Sinkronisasi penyediaan benih sumber (breeder seed dan foundation seed) bagi kegiatan produksi benih selanjutnya; (3) Sinkronisasi proses produksi benih dengan aspek-aspek persyaratan benih bermutu, seperti ketepatan varietas, ketepatan jumlah, ketepatan mutu, ketepatan lokasi, ketepatan waktu, dan ketepatan harga; dan (4) Pengendalian dan pengawsan mutu benih, terutama apabila pengadaan dan distribusi benih tidak diatur dalam satu manajemen. Kegiatan partisipasi dalam produksi benih tersebut secara umum sebagai Produksi Benih Partisipatif.

\section{Preferensi Konsumen}

Preferensi konsumen dapat berarti kesukaan, pilihan atau sesuatu hal yang lebih disukai konsumen. Preferensi ini terbentuk dari persepsi konsumen terhadap produk (Munandar dkk, 2007). Assael (1992) dalam Munandar dkk, membatasi kata persepsi sebagai perhatian kepada pesan, yang mengarah ke pemahaman dan ingatan. Persepsi yang sudah mengendap dan melekat dalam pikiran akan menjadi preferensi. Mengerti dan mengadaptasi preferensi dan perilaku konsumen bukanlah pilihan, keduanya adalah kebutuhan mutlak untuk kelangsungan hidup kompetitif. Dalam analisis akhir, konsumen memegang kendali dan produk dikatakan berhasil bila dapat menawarkan manfaat yang riil.

Penilaian preferensi konsumen dapat dilakukan melalui sejumlah cara diantaranya dengan menggunakan model sikap multiatribut Fishbein (Schiffman dan Kanuk, 1994 dalam Munandar et al., 2007) dan model Kano (Widiawan et al., 2004). Model sikap multiatribut digunakan untuk mengidentifikasi bagaimana konsumen merangkai kepercayaan (belief) mereka terhadap atribut suatu produk, sehingga membentuk sikap (attitude) tentang berbagai objek. Apabila konsumen memiliki sikap yang mendukung terhadap suatu merek, maka merek tersebut yang akan dipilih dan dibeli. Selanjutnya Engel et al. (Munandar et al., 2007) menyatakan bahwa analisis sikap multiatribut dapat menjadi sumber yang kaya akan informasi yang berguna bagi perencanaan dan tindakan pasar. Selain itu, analisis sikap multiatribut juga bermanfaat dalam pengembangan suatu produk baru.

Sementara itu, menurut Kotler dan Armstrong (2008) atribut produk merupakan suatu komunikasi atas manfaat dari hasil pengembangan suatu produk atau jasa yang ditawarkan. Atribut produk terdiri atas kualitas (meliputi tingkat/positioning dan konsistensi), fitur (sarana kompetitif untuk diferensiasi produk), serta gaya dan desain (totalitas fitur yang mempengaruhi tampilan, rasa dan fitur produk berdasarkan kebutuhan inti dari produk yang akan dibeli konsumen).

\section{Integrasi Participatory Plant Breeding dan Preferensi Konsumen dalam Perakitan Varietas Kedelai Baru}

Menurut Desclaux (2005), Participatory

Plant Breeding dapat dikenali dari tujuannya (pendekatan proses atau fungsional). Pendekatan fungsional mengupayakan benih yang sesuai dengan kebutuhan petani, sementara pendekatan proses memberdayakan petani untuk memproduksi benih sendiri. Bergantung pada siapa yang memimpin proses pemuliaan atau konteks kelembagaannya PPB dibedakan atas farmer led atau formal led. Menurut bentuk interaksi antar petani dan pemulia (konsultatif/berbagi informasi, kolaboratif/ berbagi tugas, atau kolegial/berbagi tanggung jawab, pengambilan keputusan dan tanggung jawab), serta lokasi pemuliaannya (sentralisasi atau desentralisasi).

Upaya pemuliaan kedelai saat ini, seyogyanya diantisipasi tidak hanya sampai pada tingkat petani pengguna tetapi lebih jauh lagi hingga tingkat pengguna akhir, dalam hal ini para pengrajin pangan berbahan baku kedelai. Kano (Widiawan dan Irianti, 2004) mengkategorikan sejumlah atribut yang perlu dipertimbangkan dalam pengembangan produk baru menjadi: 1) Atribut yang harus dipenuhi (must be). Jika layanan itu ada, mereka tidak meningkat kepuasannya. 2) One dimensional, 
Jika ada layanan tersebut, konsumen puas. Jika terjadi sebaliknya konsumen tidak puas. 3) Attractive. Jika layanan itu diberikan, konsumen puas sekali. Sebaliknya jika tidak ada layanan tersebut, konsumen tidak kecewa.

Selain tiga kategori tersebut, Kano menyebutkan tiga kategori lainnya, yaitu reverse, indifferent dan questionable. Jika ada tidaknya suatu layanan tidak berpengaruh pada kepuasan konsumen, layanan tersebut termasuk kategori indifferent. Kategori reverse merupakan kebalikan dari one dimensional. Derajat kepuasan konsumen lebih tinggi jika layanan berlangsung tidak semestinya, dibandingkan kepuasan terhadap layanan yang berjalan dengan baik. Kategori questionnable artinya kadang kala konsumen puas atau tidak puas jika layanan itu diberikan atau tidak diberikan. Oleh karenanya, perakitan kedelai baru harus mengidentifikasi atribut apa saja termasuk kategori apa, sehingga dapat menghemat banyak pengeluaran dan energi serta dapat menentukan strategi yang lebih baik guna mencapai hasil maksimal. Secara konseptual, integrasi keduanya dapat disederhanakan ke dalam Gambar 1.

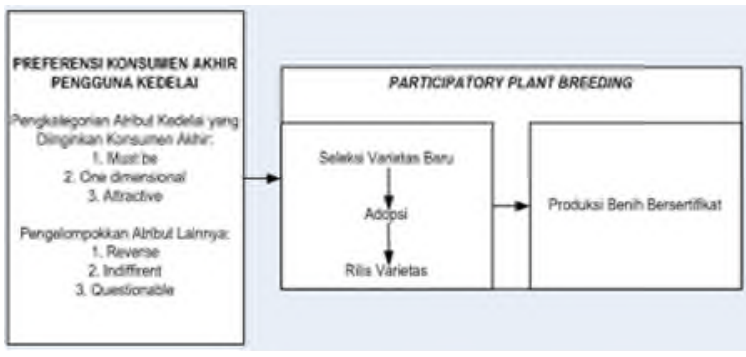

Gambar 1. Integrasi PPB dan Preferesi Konsumen dalam Pemuliaan Kedelai.

\section{KESIMPULAN}

Kegiatan pemuliaan tanaman seharusnya bersifat inklusif, mempromosikan keragaman genetik, dan responnya terhadap keragaman agroekosistem pertanaman dan sosial budaya masyarakat, serta sekaligus memberdayakan petani dan masyarakat perdesaan. Hal tersebut dapat ditempuh melalui Participatory Plant Breeding (PPB). PPB dapat dikenali dari tujuannya (pendekatan proses atau fungsional), konteks kelembagaannya (farmer led atau formal led), bentuk interaksi antar petani dan pemulia (konsultatif, kolaboratif, atau kolegial), dan lokasi pemuliaannya (sentralisasi atau desentralisasi). Kegiatan pemuliaan kedelai saat ini, seyogyanya diarahkan tidak hanya sampai pada tingkat petani pengguna tetapi lebih jauh lagi hingga tingkat pengguna akhir, dalam hal ini para pengrajin pangan berbahan baku kedelai. Dengan mengintegrasikan pendekatan PPB dan preferensi konsumen dalam pemuliaan kedelai, produksi benih kedelai yang akan ditanam oleh petani telah secara langsung mengantisipasi kebutuhan konsumen akhir (pengrajin pangan berbahan baku kedelai), yang pada akhirnya akan meningkatkan daya saing kedelai nasional Indonesia.

\section{DAFTAR PUSTAKA}

Almekinders, C.J.M. dan A. Elings. 2001. Collaboration of farmers and breeders: Participatory crop improvement in perspective. Euphytica 122:425438,2001. Kluwer Academic Publishers.

Balai Penelitian Kacang-kacangan dan Umbiumbian. 2008. Mutu Kedelai Nasional Lebih Baik dari Kedelai Impor. Warta Penelitian dan Pengembangan Pertanian Vol. 30 No. 1

Bänziger, M., and M. Cooper. 2001. Breeding for low input conditions and consequences for participatory plant breeding: Examples from tropical maize and wheat. Euphytica 122: 503-519.

Balitbangtan Irja. 2000. Teknologi Produksi Benih Kedelai. Departemen Pertanian Badan Penelitian dan Pengembangan Pertanian, Loka Pengkajian Teknologi Pertanian Koya Barat, Irian Jaya

Ceccarelli, S., S. Grando, R. Tutwiler, J. Baha, A.M. Martini, H. Salahieh, A. Goodchild, and M. Michael. 2000. A methodological study on participatory barley breeding. I. Selection phase. Euphytica 111: 91-104.

Ceccarelli, Salvatore, S. Grando, E. Bailey, A. Amri, M. El-Felah, F. Nassif, S. Rezgui, and A.Yahyaoui. 2001. Farmer participation in barley breeding in Syria, Morocco and Tunisia. Euphytica 122: 521-536.

Ceccarelli, Salvatore dan Stefania Grando. 2007. Decentralized-participatory plant breeding: an example of demand driven research. Euphytica (2007) 155:349-360. Springe Science+ Business Media B.V.

Courtois, B., B. Bartholome, D. Chaudhary, G. McLaren, C.H. Misra, N.P. Mandal, S. Pandey, T. Paris, C. Piggin, K. Prasad, A.T.Roy, R.K. Sahu, V.N. Sahu, S. Sarkarung, S.K. Sharma, A. Singh, H.N. Singh, O.N. Singh, N.K. Singh, R.K. Singh, R.K. Singh, S. Singh, P.K. Sinha, 
B.V.S. Sisodia, and R. Takhur. 2001. Comparing farmers and breeders rankings in varietal selection for lowinput environments: A case study of rainfed rice in eastern India. Euphytica 122: 537-550.

CGPRT. 1987. Sistem Komoditas Kedelai di Indonesia. Pusat Palawija.

Elings, Anne, Conny J.M. Almekinders, Piet Stam. 2001. Why Focus the Thinking on Participatory Plant Breeding?. Euphytica 122: 423-424, 2001. Kluwer Academic Publishers Introduction:

Facino, Andi. 2012. Penawaran Kedelai Dunia dan Permintaan Impor Kedelai Indonesia serta Kebijakan Perkedelaian Nasional. Skripsi Departemen Agribisnis Fakultas Ekonomi Dan Manajemen Institut Pertanian Bogor.

Falconer, D.S. and T.F.C. Mackay. 1996. Introduction to Quantitative Genetics. Longmann. Malaysia

Kaindaneh, P.M. 2006. Technology Transfer from the Adaptive Crop Research and Extension Project in Sierra Leone. http://www.idrc.ca/en/ev-30813-201-IDO TOPIC. Diakses tanggal 10 Juni 2011.

Kementan. 2013. Deskripsi Varietas Unggul Kedelai 1918-2012. Kementerian Pertanian Republik Indonesia.

Kotler, Philip dan Amstrong, Gary. 2008. Prinsip-Prinsip Pemasaran. Edisi 12, Jilid 1. Jakarta : Erlangga

Krisdiana, R. 2014. Penyebaran varietas unggul kedelai dan dampaknya terhadap ekonomi perdesaan. Penelitian Pertanian Tanaman Pangan 33 (1) : 61 - 69.

Machado, A. T., and M. S. Fernandes. 2001. Participatory maize breeding for low nitrogen tolerance. Euphytica 122: 567573.
Munandar, Jono M., Faqih Udin dan Meivita Amelia. 2007. Analisis Faktor yang Mempengaruhi Preferensi Konsumen Produk Air Minum dalam Kemasan di Bogor. J. Tek. Ind. Pert. Vol. 13(3), 97107

Rachmadi, M., A.A. Wijaya, B. Waluyo, dan A. Ismail. 2015. Interaksi Genotipe $x$ Lingkungan dan Seleksi Genotipegenotipe Kedelai pada Pertanaman Tumpangsari dengan Jagung. Makalah Seminar Nasional Perhimpunan Agronomi Indonesia (PERAGI), Surakarta, 13 - 14 November 2014.

Rachmadi, M. 2016. Peran Pemuliaan Tanaman dalam Industri Perbenihan Mandiri untuk Membangun Kedaulatan Pangan dan Indutsri. Makalah Pembahasa dalam Seminar Nasional dan Kongres Perhimpunan Agronomi Indonesia (PERAGI), Bogor, 27 April 2016.

Sobir. 2005. Pemuliaan Tanaman Partisipatif (PTP) dan Percepatan Perakitan Varietas. Dalam Kemeterian Negara Riset dan Teknologi Republik Indonesia. Participatory Plant Breeding. Pusat Kajian Buah-buahan Tropika, Lembaga Penelitian dan Pemberdayaan Masyarakat, Institut Pertanian Bogor.

Sperling, L. J.A. Ashby, M.E. Smith, E. Weltzien, S. Mc Guire. 2001. A Framework for Analyzing Participatory Plant Breeding Approaches and Results. Artikel pada Seminar Sélection participative, Montpellier, 5-6 September 2001.

Widiawan, Kriswanto dan Irianty. 2004. Pemetaan Preferensi Konsumen Supermarket dengan Metode Kano Berdasarkan Dimensi Servqual. Jurnal Teknik Industri Vol. 6, No. 1, Juni 2004: $37-46$. 